\title{
Analysis of shock metamorphic processes in the Zagami meteorite
}

\author{
Ildikó Gyollai $^{1,2} *$, Ákos Kereszturi ${ }^{2}$, Elias Chatzitheodoridis ${ }^{3}$ \\ ${ }^{1}$ Geobiomineralization and Astrobiology Research Group, HAS Research Centre for Astronomy and Earth \\ Sciences, Institute for Geological and Geochemical Research, Budapest, Hungary \\ ${ }^{2}$ Konkoly Thege Miklós Astronomical Institute, HAS Research Centre for Astronomy and Earth Sciences, \\ Budapest, Hungary \\ ${ }^{3}$ Department of Geological Sciences, School of Mining and Metallurgical Engineering, National Technical \\ University of Athens, Athens, Greece
}

Received: May 22, 2018; accepted: December 5, 2018

The study of shock-metamorphic features of the Zagami meteorite revealed pseudotachylite-like melt veins with inhomogeneous chemistry and schlieren structure of silica-glass and alkali feldspar melt glass. The feldspar occurs as diaplectic glass in the interstitial area indicating short-time (few seconds) quenching of shock pressure during the impact event, with post-shock annealing. At several locations, apatite needles were identified, which are formed by fluids (cold water with dissolved ions) after the crystallization of cumulate magmatic minerals. Phosphates also could form in impact melts due to circulation of fluids after the impact event. The other signature for the high shock temperature is the presence of Ca-Ti-rich pyroxenes and titanomagnetite, which indicate temperature above $1,200{ }^{\circ} \mathrm{C}$. The formation of silica-rich melt in interstitial area has two scenarios: (a) fractional melting of the Martian crust or (b) formation by pseudotachylite-like impact melting. According to textural observations (schlieren pattern), we propose an impact origin of the large amount of silica-rich melt in this meteorite. Pseudotachylite-like textures were mentioned earlier in terrestrial impact craters; however, we first propose them to form in a Martian meteorite based on their similarity of texture with terrestrial pseudotachylites.

Keywords: meteorites, shock features, Zagami meteorite, BSE imaging, impact melt, schlieren structure, pseudotachylite

*Corresponding author: Ildikó Gyollai; Geobiomineralization and Astrobiology Research Group, HAS Research Centre for Astronomy and Earth Sciences, Institute for Geological and Geochemical Research, Budaörsi út 45., H-1112 Budapest, Hungary

E-mail: gyollai.ildiko@csfk.mta.hu

This is an open-access article distributed under the terms of the Creative Commons Attribution-NonCommercial 4.0 International License, which permits unrestricted use, distribution, and reproduction in any medium for noncommercial purposes, provided the original author and source are credited, a link to the CC License is provided, and changes - if any - are indicated. 


\section{Introduction}

The Zagami meteorite fell on October 3, 1962, about 0.75 miles from Zagami Rock, Katsina Province, Nigeria (Graham et al. 1985). It was the second meteorite found to contain a significant amounts of trapped Martian atmospheric gases (Marti et al. 1995) and belongs to the shergottite Martian meteorite group; thus, it could provide clues to the mineralogical complexity of the Martian mantle (Langenhorst and Poirier 2000). The plagioclase was transformed to shock-induced diaplectic glass; minor components are pyrrhotite, whitlockite, and titanomagnetite of magmatic origin (Nyquist et al. 2001). In the terrestrial environment, similar silica-rich melt could form by melting along the grain boundaries of silicate minerals (Kelemen et al. 1998), for example, by impact-driven frictional heating (Haughton structure - Osinski 2007). The silicate melt is observed to be distributed within the rock matrix and not only in the fusion crust; hence, any contamination (due to its impact on Earth) is excluded, since the meteorite was not subjected to elevated temperature. All of the silica-rich melt most probably has a Martian origin.

The high-pressure phases in the Zagami were detected inside the thick, black shock-melt veins (Langenhorst and Poirier 2000), containing high pressure-temperature ( $\mathrm{p}-\mathrm{T}$ ) minerals: stishovite, $\mathrm{K}-\mathrm{Na}-\mathrm{Ca}$ hollandite, akimotoite, silicate perovskite, and ferro-magnesian silicate titanite (Langenhorst and Poirier 2000). These minerals suggest that these black veins have been formed by rapid shear melting while solidification took place in a very short time period, during partial crystallization. At the grain boundaries of minerals occurring in the black veins, Langenhorst and Poirier (2000) observed the decomposition of silicate perovskite to a lower pressure assemblage of wüstite and stishovite, which occurs at shock pressure of $24 \mathrm{GPa}$. According to Nyquist et al. (2001), peak shock pressures in Martian meteorites are estimated between 15 and $45 \mathrm{GPa}$, and in special case of shergottites were between 29 and $45 \mathrm{GPa}$. These estimations are a result of the refractive index measurements in maskelynites (Nyquist et al. 2001 and references therein).

The Zagami has an ejection age 3 Ma based on ${ }^{37} \mathrm{Ar}$ geochronology of pyroxene (Eugster et al. 1997; Nyquist et al. 2001). Mineralogically consists predominately of augite and pigeonite, showing irregular chemical zoning toward their Fe-rich rim in shock veins. The Ar-39/Ar-40 age estimation for the maskelynite in Zagami was measured to be around 250-260 Ma. The amphibole inclusions in Mg-rich cores of pyroxene indicate the presence of a magma chamber of Zagami at roughly $7.5 \mathrm{~km}$ depth (McCoy et al. 1992; Nyquist et al. 2001). The Nakhla and Zagami meteorites originated as two main ejection groups from craters of around 100 and $200 \mathrm{~km}$ diameter (Vickery and Melosh 1987), which have a young igneous crystallization ages of about $165 \mathrm{Ma}$ of the parent magma, suggesting that Martian volcanism should have been active until almost recently (Warren 1994). The goal of our research is to evaluate scenarios determining whether the silica and feldspar melt is of impact origin or by fractional melting processes of Martian crust (i.e., partial melting and fractional crystallization due to magmatic differentiation). 
In this study, we specially aim to better understand the shock metamorphic processes, including the original characteristics of the shock-related alteration, that is, whether pseudotachylite-like impact melting occurred along earlier fractures [supported by the coexistence of maskelynite (a diaplectic feldspar glass) and the silica glass], or fractional melting of the Martian crust (supported by the presence of tiny 1-3 $\mu \mathrm{m}$ zircon grains). Zircons form during the fractional melting of recycled magmatic rocks in the upper mantle (Westall 2016). Beyond these parameters, we also focus on the mineral destruction; the element migration and the formation of new phases occur in order to highlight the conditions of alterations occurring in the microscopic scale.

Based on earlier publications, many impact melt zones indicative of high temperature are present in Zagami (Malavergne et al. 2001); cristobalite polymorphs could be the result of back-transformation of post-stishovite silica polymorphs. Highly heterogeneous shock conditions were observed at a few micrometer spatial distances (Malavergne et al. 2001). In the black melt veins stishovite, $\mathrm{K}$ - and Na-, Ca-rich hollandite, akimotoite, and amorphous grains of silicate perovskite composition were identified (Langenhorst and Poirier 2000). Min and Farah (2011) estimated 213-407 ${ }^{\circ} \mathrm{C}$ peak shock temperature and $220-270{ }^{\circ} \mathrm{C}$ post-shock temperature at the normal Martian surface temperature being at $-70{ }^{\circ} \mathrm{C}$, according to He-diffusion properties of the merrillite model.

\section{Materials and Methods}

Our Zagami meteorite sample is a polished thick section of three distinct pieces (about $2 \times 4 \mathrm{~mm}, 4.5 \times 2 \mathrm{~mm}, 4 \times 7 \mathrm{~mm}$ each) embedded in Canada balsam. During the work, the sample's area was subdivided to a matrix to firmly label certain components. These codes are indicated in this paper in brackets.

Scanning electron microscope-backscattered electron imaging and electron microprobe were carried out at the School of Mining and Metallurgical Engineering of the National Technical University of Athens, Greece. All elements were analyzed by energy-dispersive X-rays (EDX) using a liquid nitrogen-cooled EDX detector (Oxford systems, AztecLive, live EDS imaging combines with X-ray phase imaging; https://nano.oxinst.com/products/aztec/azteclive), attached to a JEOL JSM 6380-LV SEM. The operating conditions of the instrument during analyses were, accelerating voltage of $20 \mathrm{kV}$, beam diameter of less than $1 \mu \mathrm{m}$, and beam current 1 $\mathrm{nA}$. High vacuum was used while counting time was $60 \mathrm{~s}$. ZAF correction software was used. Natural minerals and synthetic oxides were used as standards backscattered electrons (BSE) images acquired in slow rate of scan modes

Mineral composition was calculated using the INCA software with oxide composition in weight $\%$, and elemental composition in atom $\%$. Table 2 shows the atom $\%$ ratios of elements at each measuring point. The olivine, pyroxene, and apatite measurements have been normalized to $100 \%$ total values (because of the presence of volatiles in shock melts and in shocked minerals, in some cases there is a lot 
deviation). The EDX could not detect $\mathrm{C}$ and $\mathrm{H}$; hence, the carbonates have around $65 \%$, the clays $70 \%-79 \%$, and the serpentines $80 \%-90 \%$ total values.

The Raman spectral analysis was carried out with a Renishaw Ramascope RM1000 confocal microspectrometer of the National Technical University of Athens, using the $100 \times$ magnification objective lens (spot size smaller than $1.5 \mu \mathrm{m}$ ) of a Leica DM LM optical microscope (Germany; https://www.leica-microsystems.com/ products/light-microscopes/p/leica-dm-lm/downloads/) through which a 632.8-nm $\mathrm{He}-\mathrm{Ne}$ laser was inserted, a beam intensity on the spot of $<5 \mathrm{~mW}$, attenuated to lower energies with the use of set of neutral density optical filters when required. The entrance slit of the spectrometer was set to $50 \mu \mathrm{m}$. The spectrometer is based on a grating of 1,800 lines $/ \mathrm{mm}$ and the spectra were acquired with a Peltier-cooled CCD camera in continuous scanning mode. The spectra were the results of 5-10 accumulated scans of individual measurements, each acquired with an integration time of $10 \mathrm{~s}$.

\section{Results}

Largely open fractures without infilling of secondary minerals are the most obvious morphological features in Zagami meteorite, indicating mechanical shock effects. Melt veins were also present and are interpreted to be of following three types (Fig. 1):

1. Feldspar-melt with apatite and/or chromite (10-50 $\mu \mathrm{m}$ thick and 200-500 $\mu \mathrm{m}$ long, linked to melt pockets along the grain boundaries. The branching of melt veins is more common close to the melt pockets, with around five veins in a $500-\mu \mathrm{m}$-long area),

2. Silicate melt with zircon and titanomagnetite (on average ca. 50- $\mu$ m-thick veins, close to the melt pockets; branching was not observed; around two veins in a 500- $\mu \mathrm{m}$-long areas),

3. Mixed silicate-feldspar melt veins (10-20 $\mu \mathrm{m}$ thick, linked to melt pockets, branching to two parts, around two veins $/ 500 \mu \mathrm{m})$ with schlieren structure.

Types (1) and (2) melt veins do not contain schlieren structure. The feldspar composition area had any Raman signal neither of feldspar nor high-pressure phase transition mineral (hollandite structure); only fluorescence background was measured.

\section{Mineralogy and texture}

In the Zagami meteorite pyroxene, feldspar, oxides (magnetite and titanomagnetite), phosphates (apatite and whitlockite), and sulfides (pyrrhotite and pyrite) are identified as major magmatic minerals, iron oxides (goethite or hematite) as secondary alteration products; the alteration products could also have been terrestrial origin. The Zagami meteorite is observed to thick section containing prismatic pyroxene as cumulate mineral. The pyroxene crystals show bimodal distribution of their grain 


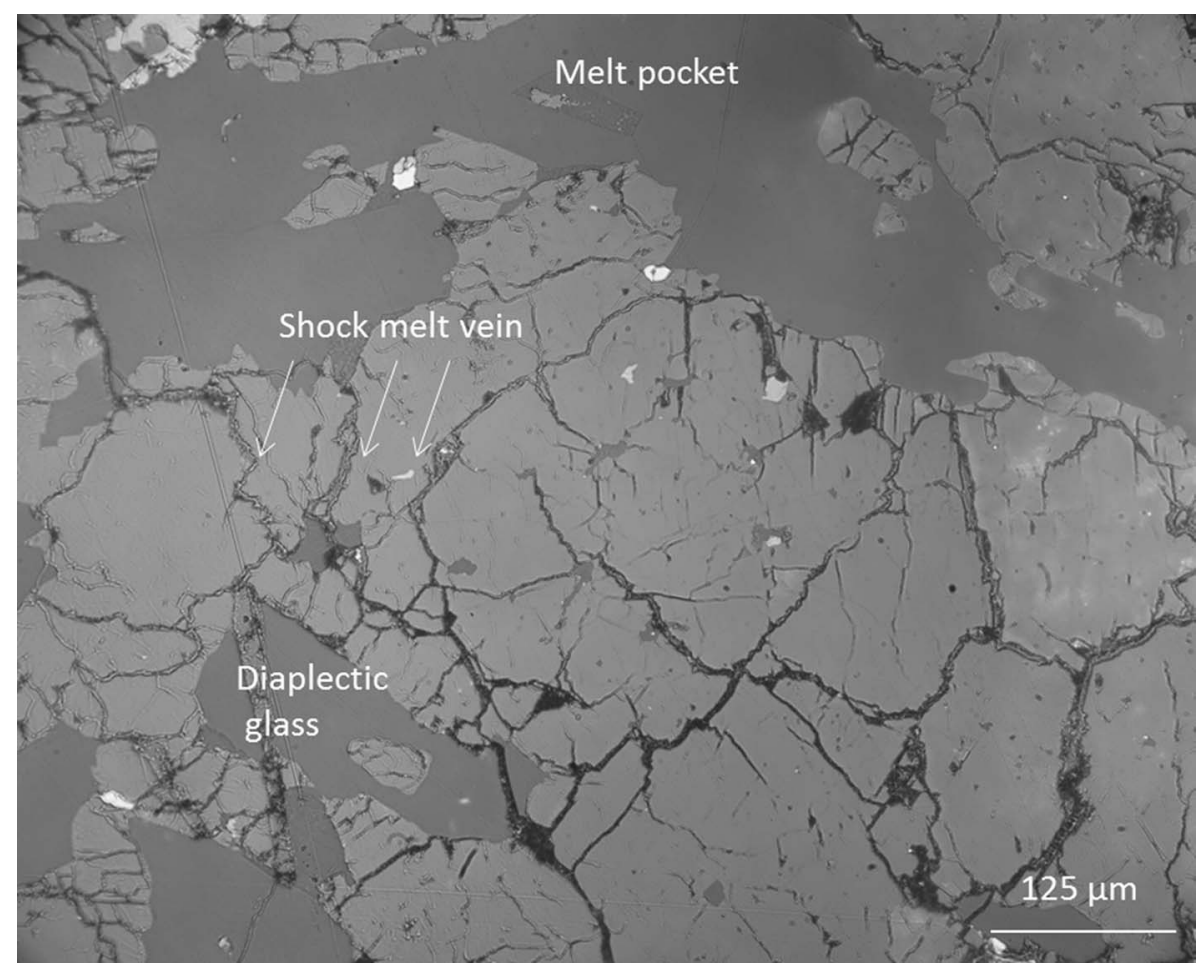

Fig. 1

Examples of the textural description from BSE images: review of the shock features in the Zagami sample. The vein types are listed in Fig. 2

size, i.e., with sites below 100 or in range of $500-1,000 \mu \mathrm{m}$. The opaque minerals (3 vol\%) in the interstitial area also show anhedral shapes, having crystallized before the formation of the melt pockets. Feldspars are present in the sample (15 vol\%) in three types of occurrence: euhedral crystals, lath-shaped crystals, and as melt in the veins of pyroxenes and in the interstitial area. Feldspars are observed as dark patches on the BSE images (Figs 2, p03-p04, p07, Site 1, Site 11 and 3). All feldspars within the interstitial area of the melt pockets have anhedral, and have a pore-filling form (Fig. 2, p03). Most of the feldspars are in melt pockets, as well as several grains from the euhedral group are amorphous, diaplectic glasses, do not show peaks during Raman spectroscopy.

The melt pockets of feldspar composition contain apatite needles (Fig. 2, Site 11) at several sites. They were identified in seven feldspar melt pockets during the electron microprobe analysis (EMPA) analysis. Locally, the apatite needles $(1-\mu \mathrm{m}$ thick, 10-25 $\mu \mathrm{m}$ long, $<1$ area\% occurrence in the whole sample) are embedded in feldspar glass (Fig. 2). The magnetite occurs in the interstitial area (1 area\%). It was identified by BSE-EDX analyses and has titanomagnetite lamellae within it 

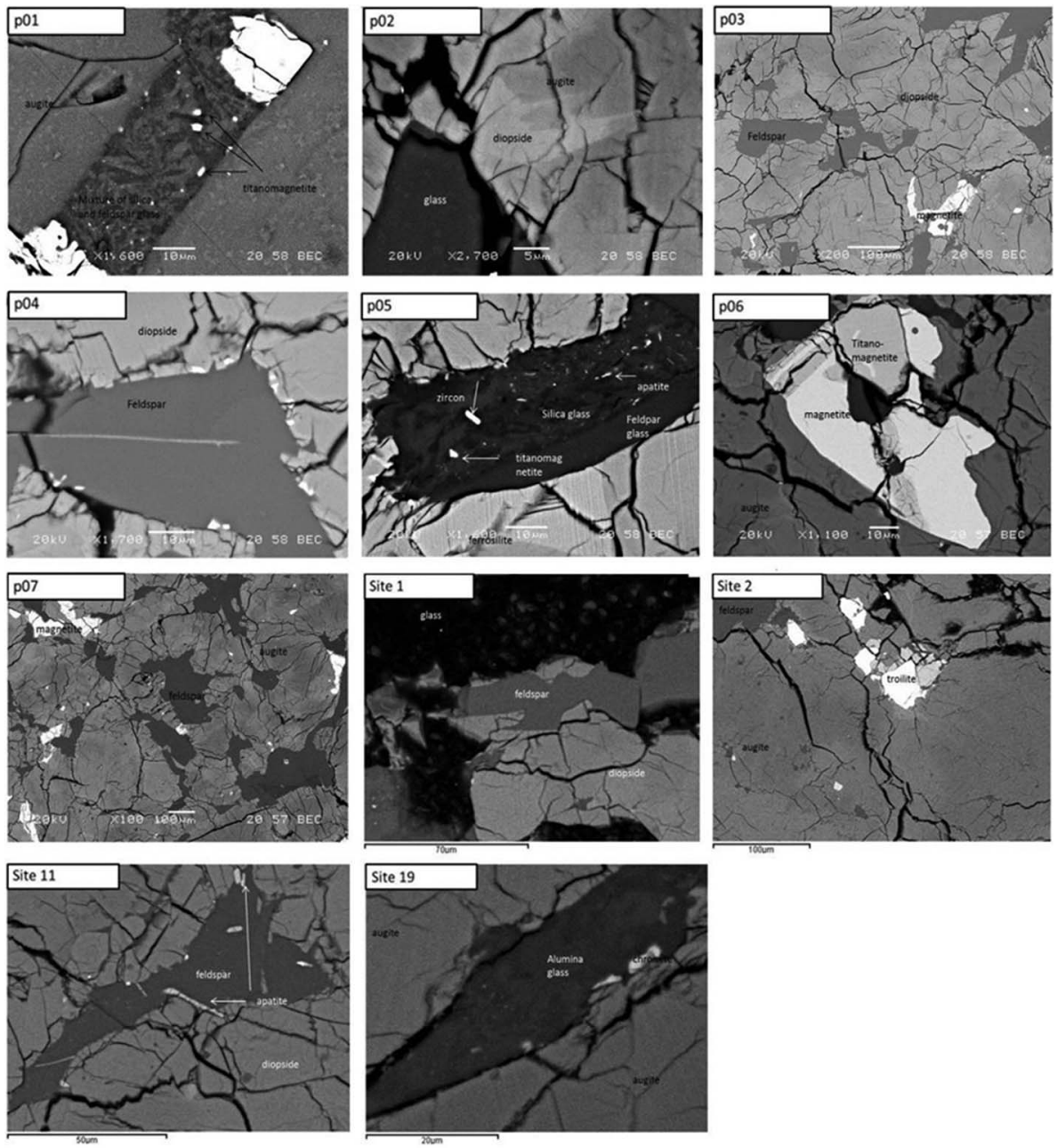

Fig. 2

p01: Shock melt silica glass in augite with titanomagnetite inclusion. p02-p04: silica and feldspar melt glass in augite, p05 inset: melt packet with magnetite, apatite, and zircon in ferrosilite. p06: magnetitetitanomagnetite immiscibility. p07: feldspar glasses in augites. Site 1: Glassy and feldspar glass in augite, Site 2: feldspar and magnetite in augite, Site 11: apatite needles in feldspar glass that has intragranular setting in augite, Site 19: alumina glass in pseudotachylite-like vein

[5- $\mu \mathrm{m}$ thick, 2- $\mu \mathrm{m}$ spacing, showing chemical immiscibility (Fig. 2, p06)]. The interstitial area among the cumulate magmatic pyroxenes is filled with diaplectic silica and feldspar glass (Fig. 2) and by opaque minerals.

Zircons have also been identified in the analyzed Zagami sample as tiny $(1-2 \mu \mathrm{m})$ minerals in the silica melt of three melt pockets (Fig. 4B). The zircon grains were 
identified by BSE imaging and EMPA analyzes, however, not chemically resolved by their host environment due to their small size. Similarly, they were not possible to be resolved by microRaman spectroscopy. All zircons occurring in the silica melt and in the melt pockets are in the vicinity of the opaque minerals. Areas 14-15 contain one grain of zircon, whereas Site 7 contains five grains of zircon [two of them have energydispersive X-ray spectrometry (EDS) chemical data] (Figs 3 and 4A-F, Tables 1-4). One of the best analyzed zircon candidates was observed at Area 12 (Fig. 4B).

Altogether seven zircon grains were identified in the studied Zagami sample, of which four grains could be analyzed. The points at Site 7 were rather mixed, whereas the grains at Areas 12 and 14 were close to ideal zircons according to their composition.

The zircon occurred in silica glass melt near to the pyroxene in the Area 14. The other group of zircon grains detected in pseudotachylite veins (glassy veins with wavy textural appearance and with mineral fragments), but these grains were mixtures with other phases like feldspar and titanomagnetite.

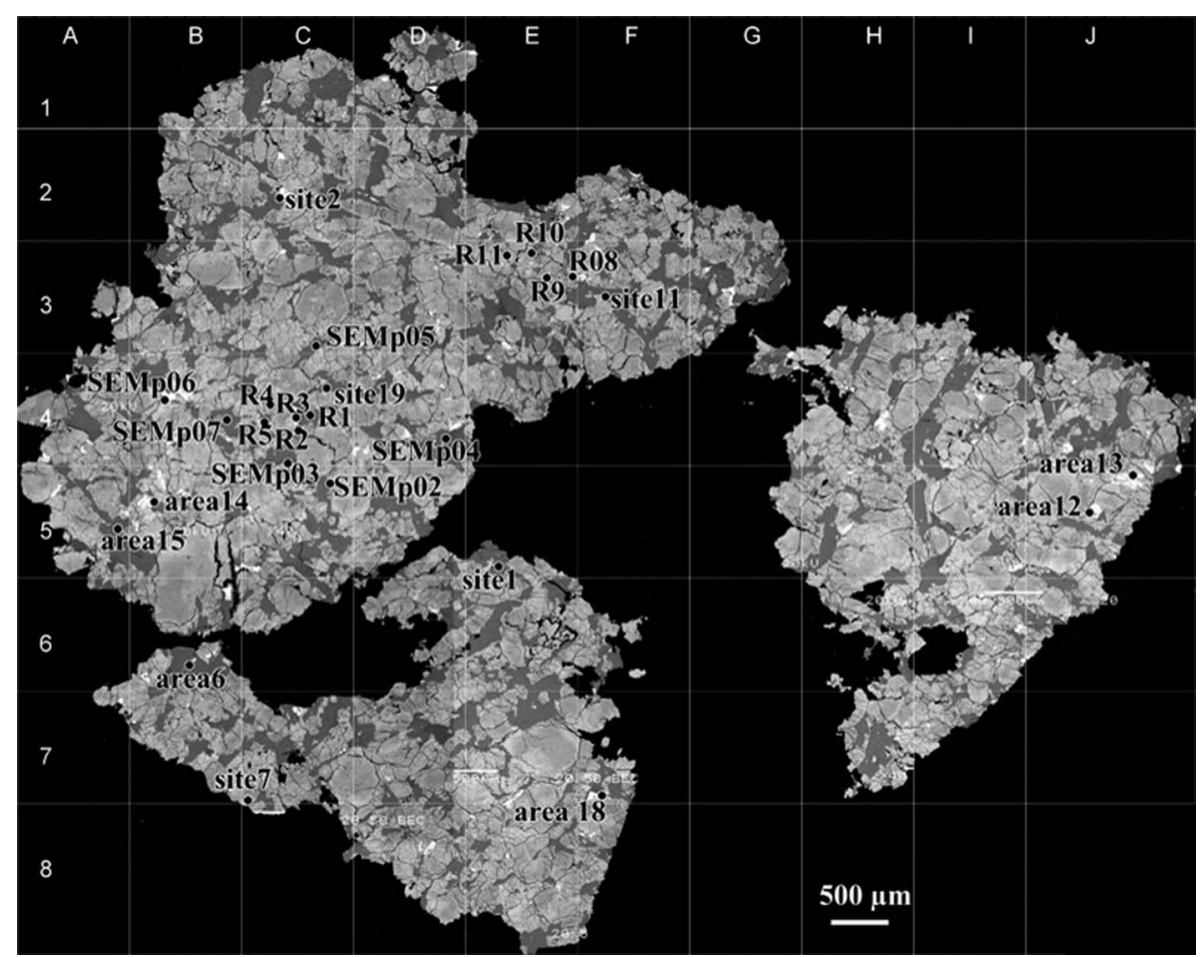

Fig. 3

Zircon-bearing area of the analyzed Zagami section on BSE image of the Zagami thick section. "R" = only Raman spectra, SEMp05, Site 1: only SEM-EDX measuring points, Area15: measured both by Raman spectroscopy and SEM-EDXs 

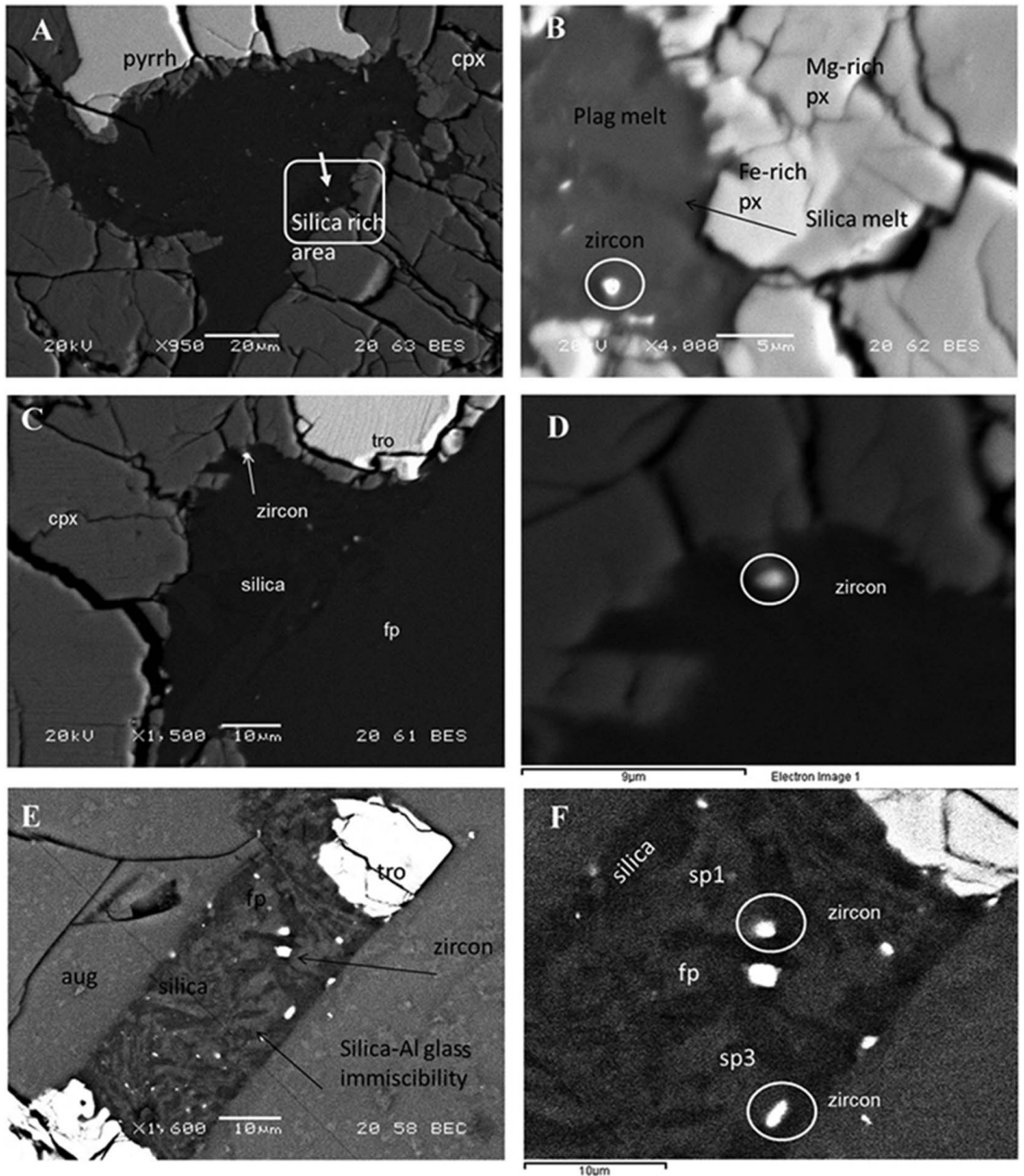

Fig. 4

(A) Zircon grain in melt pocket in the silica melt-the melt pocket is near to pyrrhotite. The zircon is marked by white arrow on the area which is marked with white rectangle. (B) Focused image of the zircon grain occurring in plagioclase rich melt pocket, but the nearby environment is composed of silica melt. The zircon occurs near the wall of zoned clinopyroxene, which shows Fe-rich composition near the melt pocket, and Mg-rich composition far from the melt pocket, (C) zircon grain in silica in the melt pocket near to wall of the pyroxene in Area 14. (D) Focused BSE image of the zircon grain in Area 14. The measured zircon grain (marked by white circle) is $0.7 \mu \mathrm{m}$. (E) Zircon grains from Site 7, their size is $0.8-1.5 \mu \mathrm{m}$. (F) Focused image of zircon measurement (Site 7, grain with 1.5- $\mu \mathrm{m}$ diameter, $\mathrm{sp} 3: 1.5 \mu \mathrm{m}$ ) 


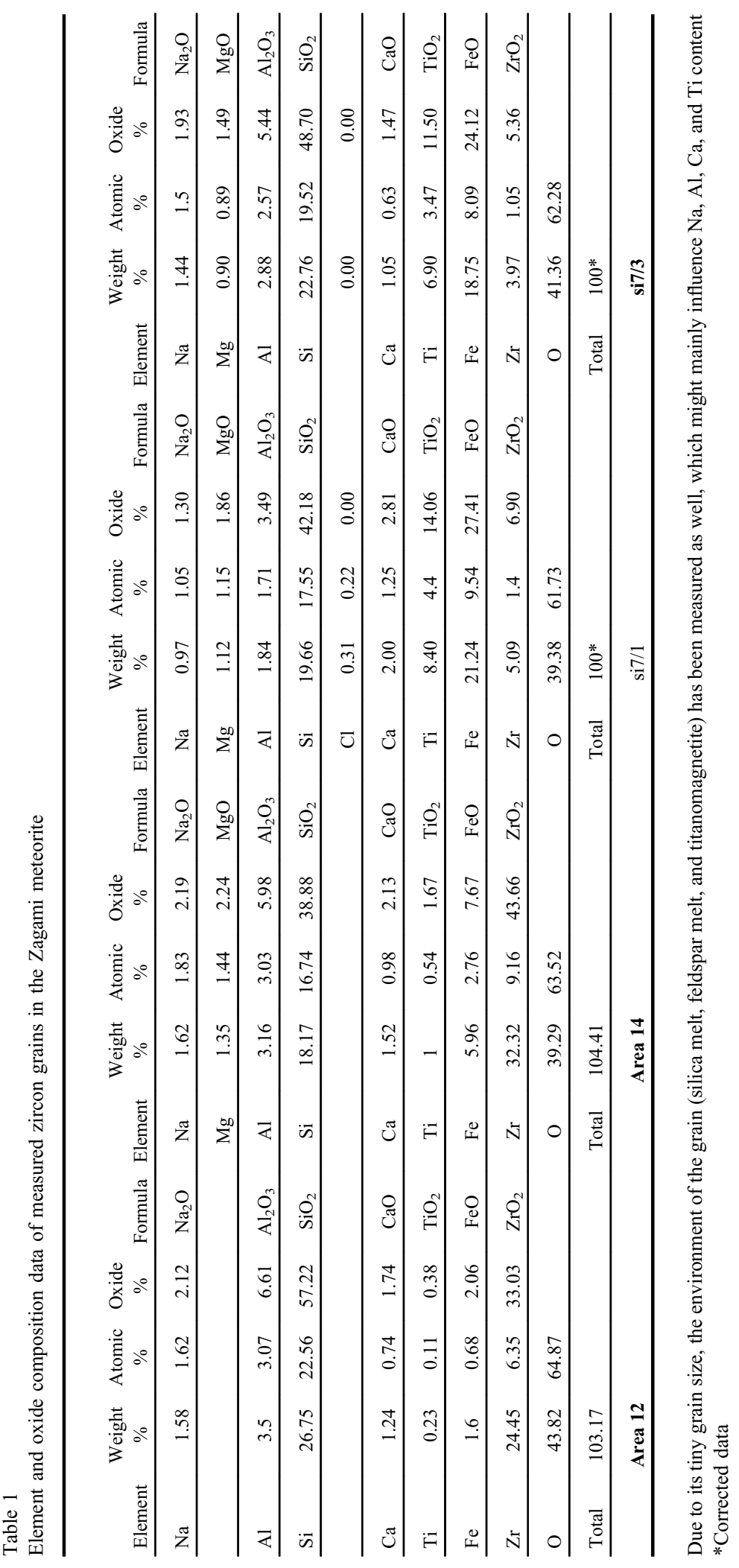




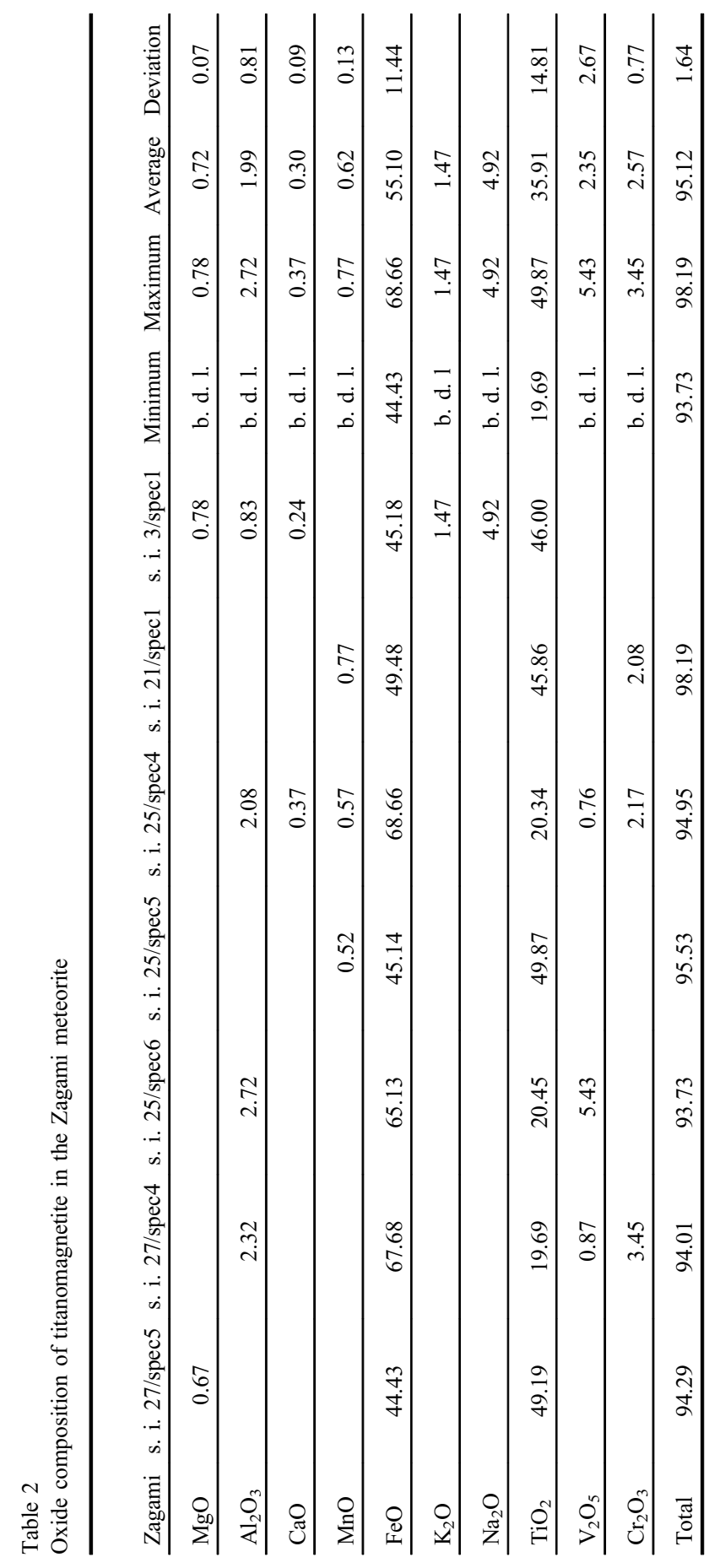

Central European Geology 62, 2019 


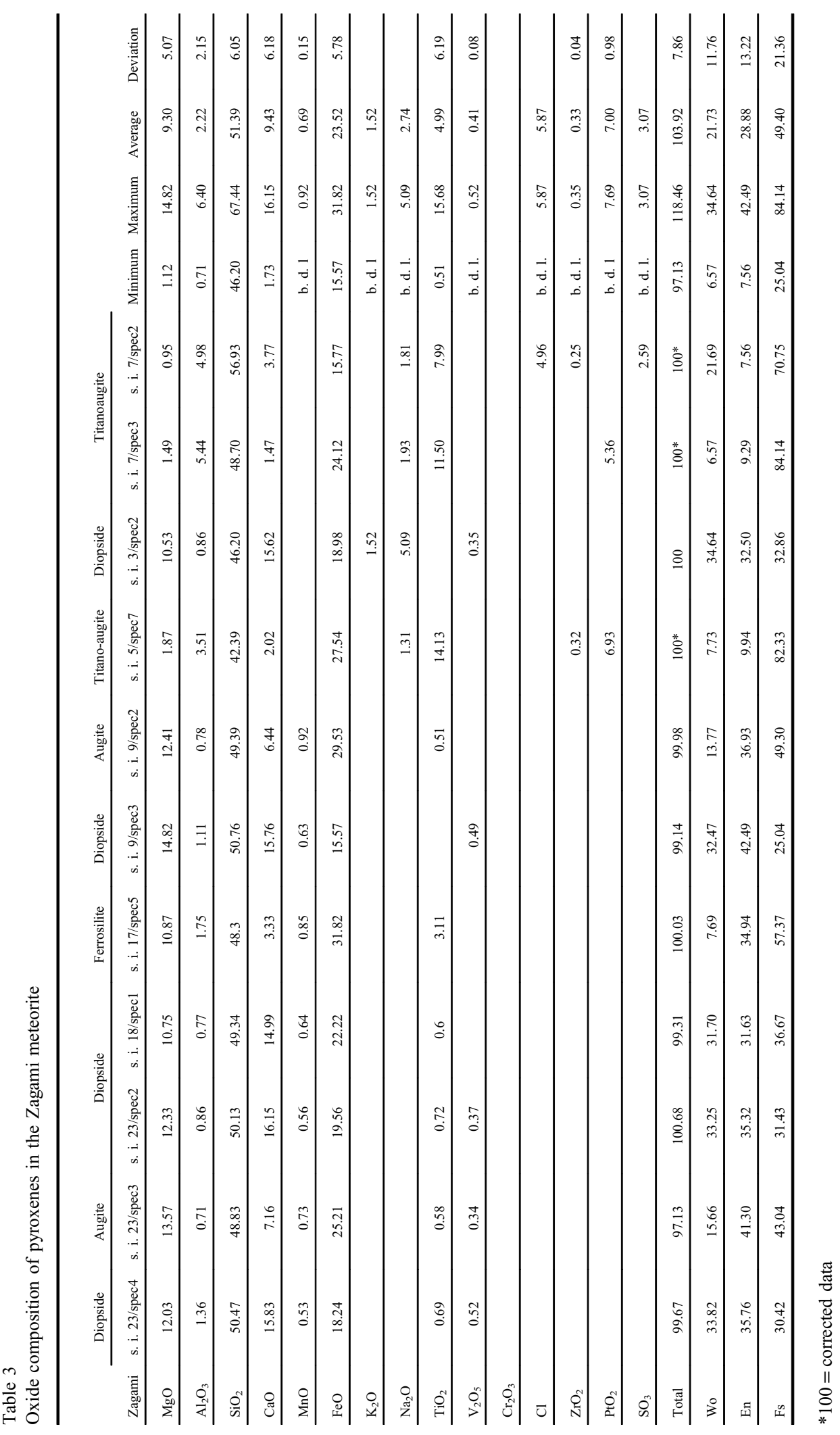




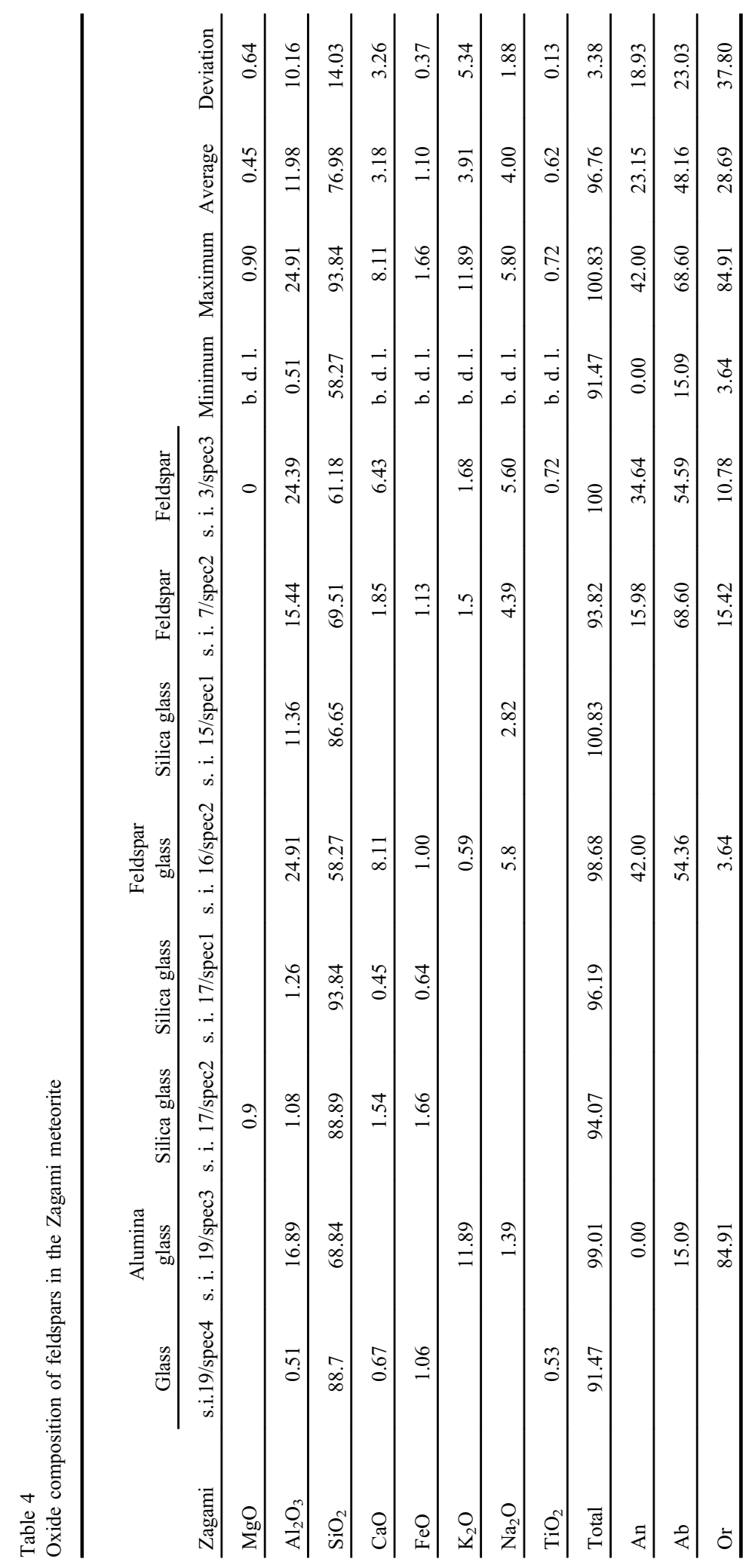




\section{Shock features}

For the morphological description of the observed shock-related features, we use the following terms:

- shock vein fractures: filled with shock-induced melt and linked to the melt pockets; their thickness varies between 10-50 m;

- schlieren structure: produced by shearing heterogeneity of the melt, producing a wavy pattern. This structure can be observed in the mixed silica and feldspar melt veins (Fig. 2), where these phases show a wavy pattern on the BSE image;

- pseudotachylite-like texture: thick silica-rich veins with around 50-m width, which contains tiny mineral clasts;

- flow-like appearance: wavy structure of veins filled with silica-rich and feldspar melt.

The sample contains four types of shock features: (a) melt pockets $(200-500 \mu \mathrm{m}$ melt-filled interstitial areas, of two pockets per $\mathrm{mm}^{2}$ occurring on average), these are glasses of amoeboid shape and (b) diaplectic glasses (100-300 $\mu \mathrm{m}$-sized, in each area of $2 \mathrm{~mm}^{2}$ ), which are Raman-amorphous minerals (but have preserved their euhedral crystal form), diaplectic feldspar glasses (maskelynite) and rounded silica grains. (c) Melt veins that occur in the pyroxenes neighboring melt pockets and diaplectic glasses. (d) The shock veins occur along fractures in pyroxenes and their thickness varies between 20 and $50 \mu \mathrm{m}$; their average density is about $1 \mathrm{vein} / 100 \mu \mathrm{m}^{2}$ (Site 19) in melt pockets (Fig. 2, p05, Sites 1, 11). Altogether, the studied Zagami sample contains about $10 \%$ silicate melt along the fractures and grain boundaries.

The melt pockets consist of a mixture of silica and alumina glasses (Fig. 2, p01, p05), with apatite and zircon inclusions or with chromite grains. The diaplectic feldspar glasses (maskelynites) show euhedral shape; the silica melt (pure $\mathrm{SiO}_{2}$ melt) and Al-rich melt $\left(\mathrm{SiO}_{2}\right.$ melt with little $\mathrm{Al}_{2} \mathrm{O}_{3}$ content) show a flow-like schlieren structure (Figs 2, p01, p05 and 4E and F), which are similar to terrestrial pseudotachylite veins.

The diaplectic feldspar glasses (maskelynite) and silicate melt pockets (together $10 \%$ of our thick section area) occur in the interstitial area among the pyroxene crystals, and in cases within the fractures near to the opaque grains (Fig. 3, dark patches in the interstitial area). The $1-\mathrm{mm}^{2}$-large melt pockets are interconnected by $50-\mu \mathrm{m}$-thick shock veins along the fractures and the grain boundaries of pyroxenes, forming a dense network. The melt pockets that are close to opaque grains contain chromite and titanite inclusions. This occurs in all of the fractures in the orthopyroxenes, and clinopyroxene glass occurs at the boundary of orthopyroxene grain and in the melt pocket.

In several cases, shock deformation microstructures (planar deformation features PDFs) and mechanical twins were observed in the pyroxenes (Fig. 2, Site 19) at the wall of shock veins and melt pockets. The shock melt forms pseudotachylite-like veins 
with schlieren structure (incongruent melting could be observed on the BSE image), where $\mathrm{Al}-\mathrm{Si}$ and $\mathrm{Si}$-rich phases show a flow-like appearance (wavy appearance of silica and feldspar melt on the BSE image; Fig. 4E and F), and pseudotachylite-like texture can be observed in silica melt veins (Fig. 2, p05, Site 19) with a schlieren structure (Fig. 2, p01, p05). The schlieren structure occurs only in silica glasses, whereas in alkali glasses only tiny mineral inclusions could be observed, like chromite and apatite. The silica-rich glasses occur as inclusions in alkali glasses, or in the vicinity of opaque grains and magmatic pyroxenes. The schlieren features also show inhomogeneity in their $\mathrm{Ca}$ and $\mathrm{Fe}$ content.

Near the glassy melt pockets, the opaque minerals crystallized immiscibility among each other: ilmenite, Cr-bearing titanomagnetite, and pyrrhotite. The clinopyroxene shows finger-like overgrowth with pyrrhotite and titanomagnetite (symplectite texture). These large opaque grains crystallized before the melt pockets formed (Fig. 5E).

The glassy melt pockets have a fibrous appearance on the BSE images (Fig. 5C) with intergrowth of silica and plagioclase composition. The euhedrally shaped, amorphous plagioclase glass and the melt pocket have no Raman signal. The detected weak Raman peak in silica glass was detected near to Cl-apatite (Figs 5A-C and 6D). The lack of Raman signal from the euhedral feldspar glasses (maskelynite) as well as most melt pockets indicates full amorphization of the crystal lattice. The presence of a weak signal of the quartz $\left(465 \mathrm{~cm}^{-1}\right)$ in the melt pocket indicates the initiation of the crystallization of the silica-melt glass (Fig. 6B). The titanomagnetite shows intergrowth textures with ilmenite and with the chlorapatite, and the chlorapatite grows at the boundary between Ti-magnetite and silicate melt pocket (Figs 5C and 6). The ilmenite and titanomagnetite have very similar Raman spectra; consequently, the best method to identify these two minerals is the BSE-EDS one.

Close to an opaque mineral (magnetite; Fig. 5E, Area 13), the pyroxene appears as intergrowth with feldspar melt pocket, possibly a reaction zone between magnetite and feldspar. According to our Raman data, both the feldspar and the clinopyroxene are poorly crystallized and do not show Raman signal, and this material could only be identified by SEM-BSE imaging and SEM-EDX measurements.

\section{Chemistry and mineralogy}

We studied the composition of interstitial glasses, olivines, pyroxenes, and magnetites to provide chemical analyses of the shock melt pockets and of their environment, using BSE imaging and the EMPA technique. The aim was to search for impact-related compositional alterations in the sample.

Titanomagnetite. The titanomagnetites in Zagami (Fig. 2, p05, p06) are characterized by $\mathrm{FeO}$ content between 44 and $69 \mathrm{wt} \%$, and $\mathrm{TiO}_{2}$ between 20 and $50 \mathrm{wt} \%$ (Table 1), with $\mathrm{Al}_{2} \mathrm{O}_{3}, \mathrm{C}_{\mathrm{r} 2} \mathrm{O}_{3}$, and $\mathrm{V}_{2} \mathrm{O}_{5}$ measuring below $5 \mathrm{wt} \%$, and $\mathrm{CaO}-\mathrm{MnO}$ below $1 \mathrm{wt} \%$ (Table 2). The titanomagnetites occur near to the shocked Ti-rich pyroxenes, near to $\mathrm{SiO}_{2}$-rich melt pockets and feldspar glasses, but not near the 

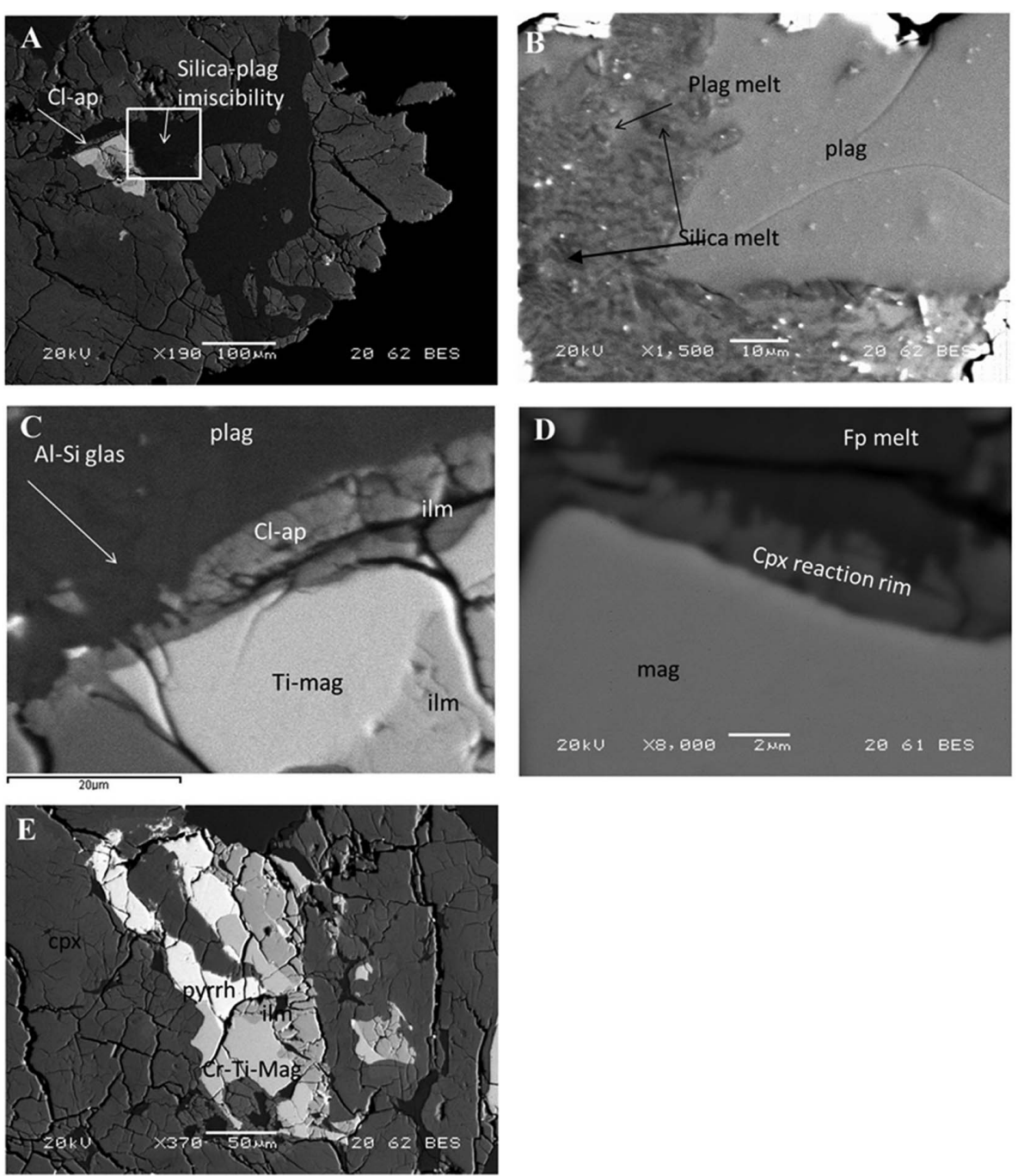

Fig. 5

(A-B) Silicate melt pocket in Area 18 with vesicular texture (C) and crystallization of chlorine-apatite at the boundary of plagioclase melt and silicate melt pocket. (D) Reaction zone between magnetite and feldspar melt and clinopyroxene. The material of clinopyroxene was mobilized by reaction of feldspar and magnetite at Area 13. (E) Symplectic growth of opaque minerals and silicate melt pockets of Area 15

unshocked pyroxenes. The highest $\mathrm{TiO}_{2}$ values of the titanomagnetites were observed for those grains, which are inside the shock melt pockets (seven grains, Table 2).

Pyroxenes. The Zagami pyroxenes could be distinguished as augites, diopsides, and ferrosilites (Table 2). Several pyroxene grains have high $\mathrm{TiO}_{2}$ content $(9-16 \mathrm{wt} \%$ ); 

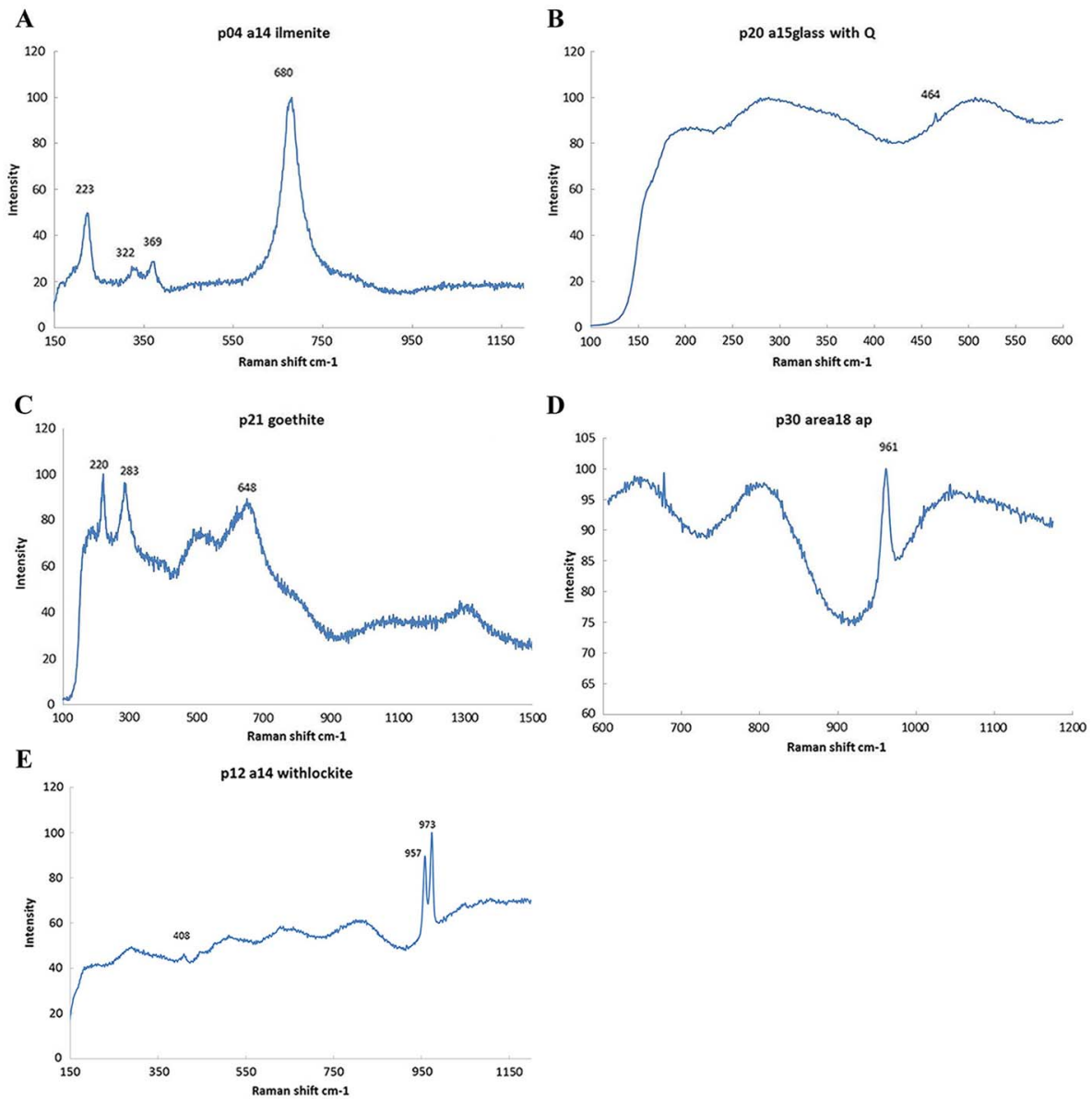

Fig. 6

Raman spectra of shock melt pockets Area 14 (A, C), Area 15 (B), and Area 18 (D). Area 14 contains ilmenite (A), and goethite as fracture filling (Spectrum C). The glass melt pocket contains a weak intense band of quartz at $464 \mathrm{~cm}^{-1}$ (Spectrum B). Area 18 contains apatite at the boundary of the shock melt pocket (Spectrum D), whereas in Area 14 withlockite was crystallized (Spectrum E)

these pyroxenes were identified as titanoaugite. The elevated Ti content in pyroxene grains occurs near to the shock melt pockets (distances of 10-30 $\mu \mathrm{m}$ ). The other pyroxenes, which are farther from shock melt pockets, have averagely $\mathrm{TiO}_{2}$ content below $1 \%$, but this value could reach $3.1 \mathrm{wt} \%$ in case of Fe-rich pyroxenes. The pyroxenes contain $\mathrm{V}_{2} \mathrm{O}_{5}$ below $0.5 \mathrm{wt} \%$; these $\mathrm{V}$-bearing pyroxene grains occur close to the melt pockets. The diopsides and the ferrosilite contain $\mathrm{CaO}$ near to $15 \mathrm{wt} \%$, whereas the augites are characterized by $6-7 \mathrm{wt} \% \mathrm{CaO}$, while all pyroxene grains 
have $\mathrm{MnO}$ below $1 \mathrm{wt} \%$. The increase of $\mathrm{CaO}$ (with $\mathrm{Al}_{2} \mathrm{O}_{3}$ and $\mathrm{TiO}_{2}$ ) to $\mathrm{MgO}$ and $\mathrm{FeO}$ content ( $\mathrm{Ca}-\mathrm{Mg}$-rich part: diopside, $\mathrm{Fe}-\mathrm{Mg}$-rich part: augite, in Fig. 2, p02) can be observed in our shocked pyroxenes (the unshocked pyroxenes are Mg-rich, and chemical inhomogeneity could not be observed). The less-shocked pyroxenes have a homogeneous Mg-rich cores and Fe-rich rim, whereas the shocked pyroxenes have a Mg-rich core (Fig. 2, p02, p07) and Ca-rich compositions close to the melt pockets.

The titanoaugites (shocked pyroxenes) contain more $\mathrm{Al}_{2} \mathrm{O}_{3}(3-6 \mathrm{wt} \%$ ) than the less-shocked pyroxenes $(0.8-1.8 \mathrm{wt} \%)$. Generally, the measured pyroxenes have $20 \mathrm{wt} \% \mathrm{FeO}$ content, with the highest values (near to $30 \mathrm{wt} \%$ ) occurring in ferrosilites and titanomagnetites. The $\mathrm{MgO}$ content varies between 10 and $15 \mathrm{wt} \%$ in most of pyroxene grains; the titanoaugites, however, have a very low $\mathrm{MgO}$ content with 1-2 wt $\%$. The less-shocked pyroxenes have a higher Mg content, while the shocked pyroxenes are rich in $\mathrm{Fe}$ and $\mathrm{Ti}$. The shocked pyroxenes occur close to the melt pockets and titanomagnetites; they contain more alkaline elements and $\mathrm{Al}_{2} \mathrm{O}_{3}$ than the other magmatic augites. The less-shocked pyroxenes contain $\mathrm{Al}_{2} \mathrm{O}_{3}$ below $1 \mathrm{wt} \%$, whereas the more-shocked pyroxenes have an $\mathrm{Al}_{2} \mathrm{O}_{3}$ content between 1.1 and $6 \mathrm{wt} \%$. (Table 3).

Feldspars and glasses. The Zagami feldspars contain 15-24 wt $\% \mathrm{Al}_{2} \mathrm{O}_{3}, 4-6 \mathrm{wt} \%$ $\mathrm{Na}_{2} \mathrm{O}$, and between 1 and $7 \mathrm{wt} \% \mathrm{CaO} . \mathrm{K}_{2} \mathrm{O}$ is around $1.5 \mathrm{wt} \%$, occurring as diaplectic glass (maskelynite) between augites. The shock veins are composed of schlierentextured glasses, which look similar in texture and composition to pseudotachylites in terrestrial impactites; the apatite inclusions occur in feldspar glass. The glasses could be subdivided into aluminum-rich ( $69 \mathrm{wt} \% \mathrm{SiO}_{2}, 12 \mathrm{wt} \% \mathrm{~K}_{2} \mathrm{O}$, and $19 \mathrm{wt} \% \mathrm{Al}_{2} \mathrm{O}_{3}$ ), silica (88-94 wt\% $\mathrm{SiO}_{2}$ ), and feldspar glasses (62 wt $\% \mathrm{SiO}_{2}, 12 \mathrm{wt} \% \mathrm{CaO}$, and $\left.2-6 \mathrm{wt} \% \mathrm{Na}_{2} \mathrm{O}\right)$. All of them occur in the interstitial area and contain tiny $(1-3 \mu \mathrm{m})$ mineral clasts. Feldspar-rich glass contains chromite and apatite; the silica-rich melt glass contains zircon, titanomagnetite, and apatite. The feldspar-rich glass veins have feldspar-like composition (with 58-69 wt\% $\mathrm{SiO}_{2}$ content). According to Raman measurements, all of feldspars and silica glasses are amorphous, identified by the lack of Raman signal. The silica-rich glasses have $\mathrm{SiO}_{2}$ content about 86-93 wt\%, incorporating $\mathrm{Al}_{2} \mathrm{O}_{3}, \mathrm{CaO}, \mathrm{TiO}_{2}$ near $0.5 \mathrm{wt} \%, \mathrm{FeO}$ below $2 \mathrm{wt} \%$, and $\mathrm{Na}_{2} \mathrm{O}$ below $3 \mathrm{wt} \%$. The incorporated elements come from the environment due to shock melting. The alumina glass (K-rich glass, similar $\mathrm{SiO}_{2}$ composition to feldspar glass) contains $\mathrm{SiO}_{2}$ near $70 \mathrm{wt} \%, \mathrm{Al}_{2} \mathrm{O}_{3}$ near $17 \mathrm{wt} \%$, and $\mathrm{K}_{2} \mathrm{O}$ near $12 \mathrm{wt} \%$ (Table 4), indicating a composition transition to feldspar. The glasses have a greater concentration of alkaline elements than the non-shocked augites (Tables 1 and 4).

\section{Raman spectroscopy of Zagami meteorite}

The major band of pyroxenes changes with iron content: the iron-rich pyroxenes have their band at $995 \mathrm{~cm}^{-1}$, whereas the $\mathrm{Mg}$-rich pyroxenes have theirs near 
$1,010 \mathrm{~cm}^{-1}$, according to the references (RRUFF project; Lafuente et al. 2015). The lath-shaped feldspar pseudomorphs, which were detected by SEM, are amorphous: they do not have a Raman signal. Since the feldspars preserved the original, euhedral crystal forms between the pyroxene grains, but as they have no Raman signal, they could be interpreted as maskelynite (diaplectic feldspar glass).

The melt pockets, which were identified by SEM (as feldspar and silica composition) show no Raman signal), and are all of them are interpreted to be amorphous glass. In one case, the silica melt has a weak Raman band at $465 \mathrm{~cm}^{-1}$, which corresponds to quartz, indicating the initiation of crystallization of quartz after the shock event.

The silica and feldspar-composition melt pockets contain needle-like inclusions of opaque minerals: ilmenite (major bands at 370 and $678 \mathrm{~cm}^{-1}$ ) and titanomagnetite (187 and $654 \mathrm{~cm}^{-1}$ ).

In the Zagami meteorite, two types of phosphate could be identified only with Raman spectroscopy: apatite (band near $960 \mathrm{~cm}^{-1}$ ) and whitlockite (doublet at 958 and $974 \mathrm{~cm}^{-1}$ ).

Raman spectroscopy is also a powerful tool to detect the signatures of secondary mineral formation, such as iron oxides, which occur near the fractures and close to opaque minerals. The iron hydroxides and oxides goethite $\left(280\right.$ and $\left.645 \mathrm{~cm}^{-1}\right)$ and hematite (220 and $290 \mathrm{~cm}^{-1}$ ) have been identified. Zagami is a "fall-meteorite" and was collected immediately after suggesting that the iron oxide minerals could be expected to have a Martian origin, based on their location solely within the fractures of opaque material; however, an Earth-based formation could not yet be excluded.

\section{Discussion}

\section{Shock melt production}

The Zagami meteorite is characterized by a large amount (10 vol\%) of intergranular melt with rounded melt packets $\left(2 \mathrm{~mm}^{-2}\right)$. Unlike nakhlites, the Zagami meteorite contains only empty fractures that are not filled with secondary minerals, except with rare iron oxides. In general, the melt pockets have been developed at the grain boundaries of minerals with contrasting shock impedance (shock wave velocity multiplied by the mineral's density), e.g., between plagioclase and pyroxene (Walton and Spray 2003). The feldspars have been melted or were transformed into diaplectic glasses; the pyroxenes are fractured. The feldspars are less resistant against increasing shock $\mathrm{p}-\mathrm{T}$ than the pyroxenes: the high-pressure formation transition of pyroxene is at $22 \mathrm{GPa}$ at $1,600{ }^{\circ} \mathrm{C}$ (Chen et al. 2004), whereas amorphization of feldspar starts between 10 and $15 \mathrm{GPa}$ (Kayama et al. 2012). The duration of post-shock annealing was longer in the center of the shock vein rather than along the wall; the cooling of the shock melt started from the wall of the veins (Sharp and De Carli 2006). The shock melt pockets and veins show that mineral melts are formed by contrasting shock 
impedance, which causes anomalies in whole rock samples due to reflection and refraction of the shock waves (Stöffler et al. 1991). The large amount of shock melt $(10 \%)$ in the Zagami meteorite could be explained by long shock loading times, according to Sharp and De Carli's (2006) models on terrestrial impact events, which are high compared to other Martian meteorites (Fritz et al. 2005).

\section{Minerals in shock melt pockets}

Our melt pockets occur between zoned, Ti-rich pyroxenes (Fig. 2, p05, Site 19), and in the vicinity of diaplectic feldspars (Fig. 2, Site1), the latter formed/recrystallized by the shock effect. The feldspar occurring within the interstitial, glassy state indicates rapid cooling. Near to the zoned, Ti-rich pyroxenes, Ti-magnetite, and apatite are embedded in a feldspar melt (Fig. 2, p05), and chromites in other case (Fig. 2, Site 19). $\mathrm{Fe}, \mathrm{Ti}$, and $\mathrm{Cr}$ could be mobilized to shock melt from the opaque minerals due to increasing shock temperature (Sharp and De Carli 2006). Apatite could have crystallized from fluids of a post-impact hydrothermal system, whereas zircon crystallized in a $\mathrm{SiO}_{2}$-rich environment, where the crust melted due to the impact event. The apatite and zircon inside the shock melt pocket indicate rapid cooling; the apatite crystallized at $1,200{ }^{\circ} \mathrm{C}$, whereas zircon crystallized at post-shock temperature between 850 and $1,050{ }^{\circ} \mathrm{C}$. Indeed, the chromite and feldspar grains could have a primary origin before the impact event: they crystallized from the ultrabasic melt.

Phosphates (whitlockite and apatite) occur also at the boundary of shocked pyroxene grains and melt pockets. The tiny apatite inclusions have been crystallized during rapid cooling. The whitlockite could more likely be of magmatic origin, whereas apatite could have been formed by secondary processes as well as during post-impact hydrothermal processes. The presence of apatite in melt inclusions indicates fluid interactions after the impact event, with an equilibrium crystallization temperature of $1,000{ }^{\circ} \mathrm{C}$ (McCubbin and Nekvasil 2008). According to $\mathrm{Hu}$ et al. (2014), the apatites crystallized last from residual melt on Mars, and their coexistence with zircon shows similarity with frictional pseudotachilite of a terrestrial impact craters (Morokweng structure; Reimold et al. 1999). Such zircon- and apatite-bearing pseudotachylite-like veins were observed in our sample as well, which indicates a similar process of frictional melting in the target rock on Mars-like terrestrial impact craters. This implies that an earlier impact event could have happened on Mars, before the Zagami meteorite was ejected to space. There are few earlier publications on zircons in Martian meteorites. Treiman (2005) mentioned the presence of zircons in their studied nakhlite samples briefly, without interpretation. Nemchin et al. (2014) interpreted the origin of zircon as formed by assimilation of early crust on melt, and the ${ }^{17} \mathrm{O}$ isotopic compositions could have preserved conditions of the ancient hydrosphere and atmosphere of Mars. Ti could substitute for $\mathrm{Zr}$ in zircon and baddeleyite above $850{ }^{\circ} \mathrm{C}$ (Nemchin et al. 2014), whereas an elevated Ti content has been also observed in the measured zircon grains. 


\section{Pseudotachylites}

The pseudotachylites have been formed by extremely rapid cooling $(<1 \mathrm{~ms})$, and are characterized by chemical inhomogeneity (inherited schlieren features with poorer and richer regions in $\mathrm{Ca}$ and $\mathrm{Fe}$ ) within a $\mu \mathrm{m}$ spatial scale, because of the lack of time for mechanical mixing and homogenization (Langenhorst and Poiriere 2000). Dingwell and Webb (1989) described a temperature dependence of the shear relaxation as characteristic of a schlieren structure from a non-Newtonian melt. The formation of pseudotachylite occurs between 875 and $900{ }^{\circ} \mathrm{C}$ during an impact event (Fricke et al. 1990). Colorless schlieren structures are such shock melt with plagioclase composition, which have incompletely mixed/homogenized with other coexisting silicate and sulfide melts (Walton and Spray 2003). The alkali- and silica-rich glasses could have been formed during the shock event but were quenched before the shock pressure was completely released (Walton and Spray 2003). Melt in melt pockets could then have been remained in a liquid state after pressure release when the temperature was still elevated (Walton and Spray 2003); thus, such $\mathrm{SiO}_{2}$-feldspar melt pockets in our sample could have been formed during the post-shock annealing.

\section{Element migration}

The measured shocked pyroxenes are characterized by $\mathrm{Ca}, \mathrm{Al}$, and $\mathrm{Ti}$ enrichment compared to non-shocked pyroxenes (Table 2), and numerous titanomagnetite grains occur close to the Ti-rich pyroxenes and pseudotachylite-like veins as well as the melt pockets. The elevated $\mathrm{TiO}_{2}$ content is caused by very high temperature during the formation/alteration of pyroxenes (Wark and Lovering $1977-1,400{ }^{\circ} \mathrm{C}$ in the case of CAIs; and $1,100{ }^{\circ} \mathrm{C}$ in the case of terrestrial tholeiitic magmas - Forsythe et al. 1994). $\mathrm{Mg}$-rich cores in our pyroxenes could indicate crystallization at elevated temperature (Wark and Lovering 1977). Toward the melt pocket, the $\mathrm{Ca}, \mathrm{Al}$, and Ti content of pyroxenes increased gradually and was probably produced by crystallization of shock-released elements.

The pyroxene also occurs as intergrowth with feldspar melt pocket as a reaction zone between magnetite and feldspar. According to Kong and Xie (2003), shock melt characterized by specific elemental enrichment, especially $\mathrm{Cr}$ in pyroxene and olivine, and $\mathrm{Ti}$ in plagioclase melt, indicates solidification at around $1,000{ }^{\circ} \mathrm{C}$. According to Madsen et al. (1992), the titanomagnetite is a metastable phase, which is formed by rapid cooling $\left(5-20^{\circ} \mathrm{C} / \mathrm{min}\right)$ of the fraction of magnetite phase, in which cooling rate could be expected for our melt pockets as well. $\mathrm{CaO}$ and $\mathrm{Al}_{2} \mathrm{O}_{3}$ go from the surrounding feldspar melt, whereas the Cr titanomagnetite is built in due to high shock temperature. According to Hawkesworth et al. (1984), the Ti enrichment is an indicator for crystallization temperature above $1,000{ }^{\circ} \mathrm{C}$, which occurs near to the rim of shock melt pockets and shock veins (Ti-rich pyroxenes and titanoaugites), indicating a post-shock temperature of $1,000{ }^{\circ} \mathrm{C}$. The titanoaugites in our sample have $\mathrm{MgO}$ below $1 \%-2 \%$, which comes from surrounding other pyroxenes. The $\mathrm{Ca}$ 
and $\mathrm{Na}$ enrichment in the shock melt compared to its environment is caused by the mobilization of incompatible elements from pyroxenes to melt during the shock annealing; substitution of $\mathrm{Al}$ in pyroxenes increases with shock stage (Walton and Shaw 2009). The Ti enrichment in shocked pyroxenes and $\mathrm{Ca}-\mathrm{Na}$ enrichment in the shock melt in the Zagami sample indicate post-shock annealing at $1,200{ }^{\circ} \mathrm{C}$. The titanoaugite lamellae could have been formed during the post-shock annealing during the melt-rock interaction.

\section{Magmatic history of Zagami meteorite}

The Zagami meteorite shows variation in grain size, which implies a two-stage magmatic history (McCoy et al. 1992). However, the variation of grain size in our case displays two processes: (a) the coarse augites with euhedral feldspars formed during crystallization in a magma chamber, and (b) the melts with tiny minerals (and amorphization magmatic feldspar to diaplectic glass) formed during the Martian impact event. This textural evidence complies with the occurrence of a homogeneous $\mathrm{Mg}$ core of pyroxenes crystallized during slow cooling in the magma chamber, and the occurrence of an outer inhomogeneous FeO-rich part zone crystallized rapidly when the basaltic lava erupted on the surface (McCoy et al. 1992). This feature of variation in the $\mathrm{Fe}-\mathrm{Mg}$ content can be observed in the less-shocked pyroxenes. In another case, pyroxene shows Fe-Mg zonation (Fig. 2, p05). According to McCoy et al. (1992), the $\mathrm{Mg}$-rich core in the pyroxene in basaltic magma crystallizes at $1,150{ }^{\circ} \mathrm{C}$, which liquid had 20 vol\% crystals. Generally, our pyroxenes are of homogeneous composition (except Fig. 2, p05), which was caused by shock annealing in the case of shocked pyroxenes. The homogenization of other pyroxenes was caused by heating in the magma chamber. The lava flow cooled $0.1-1^{\circ} \mathrm{C} / \mathrm{h}$, from which it can be estimated that the Zagami magma crystallized in an at least 10-m-thick magmatic body, which is indicated by the fine exsolution lamellae of pyroxenes (McCoy et al. 1992).

\section{Post-shock annealing}

In our case, the homogeneity is caused by post-shock annealing; since the less-shocked pyroxenes that are located far away from the melt pockets actually show higher variation in the Fe- $\mathrm{Mg}$ zonation. According to Malavergne et al. (2001), the equilibrium shock pressure was ca. $31 \mathrm{GPa}$ at $1,220^{\circ} \mathrm{C}$ temperature, suggested by the presence of a high amount of shock melt and diaplectic glasses. Our observations of the (about $10 \mathrm{vol} \%$ ) shock melt leads to a similar interpretation as that of Malavergne et al. (2001), but alternatively the silica melt with zircon inclusions could also have been formed by fractional melting (Kelemen et al. 1998 - terrestrial analog) of the Martian crust. The silica melt, which contains schlieren structures, was formed during impact event, as suggested by analysis of terrestrial analogues by Osinski (2007).

It is important to note that, while the Zagami meteorite contains only shock-induced alterations, it does not contain signatures of Martian aqueous alterations and 
weathering, as opposed to Martian nakhlites (Hicks et al. 2014). This might arise because shergottites were located at a deeper subsurface zone of the Martian magma chamber than nakhlites; hence, the Zagami was not influenced by near-surface hydrothermal or weathering-related alteration processes. Another theory is the presence of hydrothermal alteration by the magmatic fluids, which was later overprinted by impact metamorphism; the hydrothermal minerals could have been broken down because of their lower $\mathrm{p}-\mathrm{T}$ stability field.

\section{Comparison with terrestrial impactites}

Our Zagami sample is shergottite with coarser grain size (which texture is similar to terrestrial gabbro), crystallized shallow depth magma chamber on Mars. The sample contains numerous pseudotachylite-like veins and melt-pockets (Fig. 2, p01, p05, Sites $1,11,19)$, formed by impact melting - in general, by melting of magmatic pyroxenes and feldspars along grain boundaries and fractures. Alternatively, the silica glass could have originally been quartz, which formed silica melt during the impact melting on Mars (Miura et al. 1993). According to Miura et al. (1993), who described maskelynites and shocked quartz aggregate in Martian meteorites, the Martian shergottitenakhlite-chassigny (SNC)-type meteorites show similarities to terrestrial impactites. Such maskelynites were detected by electron microprobe with intragranular occurrence in our sample (Fig. 2, Sites 1, 11). The shock annealing occurs as silica melt assemblage and diaplectic feldspar glass among large magmatic augites in the sample. According to our SEM + EDX data, the melt pockets and pseudotachylite-like veins contain alkali feldspar-glass, alumina glass, and silica glass (Fig. 2, p01, p05, Sites 1, 19) due to shock melting. The interstitial silica glass probably formed during shock melting by an impact event on Mars. At some locations, Zagami has pseudotachylitelike veins with 1-mm spacing (Langenhorst et al. 1991), which was observed in our sample.

\section{Shock pressure and temperature in Zagami}

According to the literature, the Zagami meteorite contains high $\mathrm{p}-\mathrm{T}$ mineral phases. The shock features occur in thin veins and black glasses; the determined peak shock is p-T $31 \pm 2 \mathrm{GPa}$ and $1,220{ }^{\circ} \mathrm{C}$ (Marti et al. 1995). El Goresy et al. (2000) and Malavergne et al. (2001) reported various "high-pressure phases" in Zagami (i.e., hollandite-structured feldspar, stishovite, "post-stishovite silica," "silicate ilmenite," "silicate perovskite," and "silicate titanite"). Our Raman analyses of Zagami did not reveal any high-pressure phases in the melt pockets, but just glasses of $\mathrm{SiO}_{2}$ and feldspar composition despite detailed study of 16 locations in melt pockets. As mentioned earlier, the only phases we found were diaplectic feldspar glass (maskelynite) and Raman-amorphous silica melt. Due to the lack of high-pressure phases, we suggest that the shock pressure in the analyzed sample did not exceed $17 \mathrm{GPa}$, and that shock temperature was probably between 1,000 and $1,200{ }^{\circ} \mathrm{C}$. According to Sharp and 
De Carli (2006), different shock p-T conditions can be preserved because of the heterogeneity in rock - and the shock wave propagation is different: (a) the shock wave propagation is higher in fracture-inducing higher peak shock $\mathrm{p}-\mathrm{T}$, generating shock melt veins; (b) the melt pockets form near the opaque minerals due to reflections of the shock vein; and (c) the high-pressure transformation minerals occur in such shock veins in melt pockets where the duration of the shock wave pulse was longer than $6 \mathrm{~s}$.

The highest shock energy was deposited in the areas of the melt pockets within 15-17 $\mathrm{GPa}$ and at $1,000-1,200{ }^{\circ} \mathrm{C}$. The veins with the schlieren structure had longer quenching times and cooling temperature was estimated to be between 800 and $850{ }^{\circ} \mathrm{C}$. The chromite-bearing feldspar melt veins have been probably crystallized with the range of $900-1,000{ }^{\circ} \mathrm{C}$ of post-shock temperature. The shock pressure even at the less shocked, fractured pyroxenes was probably between 10 and $15 \mathrm{GPa}$. The peak shock stage occurred in the melt pockets in the vicinity of the opaque grains.

The zircons in terrestrial environments are a signature of crust formation during plate tectonics (Hopkins et al. 2008), and of a protolith recycled from crustal material due to the high degree of differentiation of melt. Previously, both terrestrial and Martian zircons were investigated only by isotopic studies ( $\mathrm{U}-\mathrm{Th}, \mathrm{Pb}$, and $\mathrm{O}^{17}$ ) and by abundant rare earth elements, which could not however be compared to our major element geochemistry data. The zircons could have been crystallized in the parent rock before the shock event, and could have been remained in the impact melt (Darling et al. 2009), similarly to observations made in terrestrial impactites.

Wielicki and Harrison (2015) described zircon in lunar rocks as well, and their crystallization was estimated to range between 850 and $1,050{ }^{\circ} \mathrm{C}$. They modeled the crystallization of zircon by $2 \%$ melting of parent rock after an impact event. In this case, the zircon could be used as a shock temperature marker, but additionally could be suitable for the geochronology of the impact event. Our zircons contain Ti, which indicates that the zircon was crystallized between 850 and $1,050{ }^{\circ} \mathrm{C}$ from the magma (Watson et al. 2006). The zircons could have an impact origin, formed by melting of the Martian basaltic crust. The tiny grain size between 1.5 and $2 \mu \mathrm{m}$ implies rapid cooling; the magmatic zircons formed by slower cooling of melt with the larger grain size of crystallized zircons; the hydrothermal zircons could also be $1 \mu \mathrm{m}$ in size. According to grain size, the zircons could be crystallized by rapid cooling from impact melt, but hydrothermal origin also is possible. Shock deformation microstructures, such as PDFs or mechanical twin lamellae, have been detected in pyroxenes (Fig. 2, Site 19), suggesting shock pressure below 20 GPa but not higher because the highpressure phases are absent (Langenhorst et al. 1991). Zagami contains mechanical twins (011 orientation; Langenhorst et al. 1991) in pyroxenes, and shock deformation features (PDFs), and which have been observed in our ferrosilite (Fig. 2, p05). Twins have not been identified. The plagioclase completely altered to maskelynite, which has intragranular texture and indicates amorphization due to high shock pressure and short shock-quenching time. 


\section{Conclusions}

A thick polished section of the Zagami meteorite was analyzed with emphasis on the shock-produced features in order to obtain insights into the events of its geologic history. We found shock features like PDFs, pseudotachylite-like melt veins with schlieren structure, melt pockets, and diaplectic glasses. The shock melt occurs mostly near the opaque minerals close to melt pockets, probably due to shock impedance contrast preferentially occurring in these areas and along the earlier fractures and pores by frictional melting. The presence of a large amount (10 vol\%) of impact melts and diaplectic glasses (formed by frictional melting and shock impedance melting near the opaque minerals) and lack of high-pressure phases indicate high shock temperature but short shock pulse durations. The presence of $\mathrm{Ca}$-Ti-rich pyroxenes and of titanomagnetite indicates shock temperature higher than $1,200{ }^{\circ} \mathrm{C}$ inside the shock melt pockets and shock veins in the interstitial area.

There are two views on the observed features of shock-produced materials. Langenhorst et al. (1991) described maskelynite between augites, but Mikouchi et al. (1999) reported that those are not diaplectic glasses, but rather melted plagioclase. Because of lack of any Raman signals, we agree with Mikouchi et al. (1999), seeing only formation of shock melt, and shock pressure quenched within shorter time frame than the quenching time of shock temperature. Due to the lack of high-pressure transformation, we estimate that the shock pressure did not exceed $20 \mathrm{GPa}$, while shock temperature reach levels above $1,200{ }^{\circ} \mathrm{C}$. Moreover, the large amount of shock melts in the sample together with a lack of high-pressure phases, the duration of quenching of shock temperature was longer than that of quenching of shock pressure. Inside the melt pockets, tiny apatite and zircon crystals have been detected; the presence of apatite indicates rapid cooling starting from $1,200{ }^{\circ} \mathrm{C}$ after the shock event. Zircon might have been crystallized at post-shock temperature between 850 and $1,050{ }^{\circ} \mathrm{C}$, and because of the presence of zircon grains at the rim of the shock melt pockets, their formation could have happened during the quenching taking place after the shock event. Alternatively, zircons and apatites could have been formed by a postshock hydrothermal system. The presence of the pseudotachylite-like veins might indicate a source area location of a crater rim, following the terrestrial analog study of Osinski (2007). This is because the selective melting occurs preferentially along the preliminary fractures.

The shocked pyroxenes at the rim of the melt pockets are enriched in $\mathrm{Ca}$ and $\mathrm{Ti}$ elements that come from the shock melt from melted feldspar and titanomagnetite. These melt pockets are enriched in incompatible elements, like $\mathrm{Ca}, \mathrm{Na}, \mathrm{K}$, and $\mathrm{Ti}$, as compared to the host rock, indicating shock melting at $1,200{ }^{\circ} \mathrm{C}$.

Between the two scenarios of formation of the silica-rich glass, namely (a) the fractional melting of the Martian crust (Westall 2016) and (b) the formation of pseudotachylite-like veins by impact-related frictional melting (Reimold et al. 1999), implying an impact origin is preferred because of the observed textural features such as schlieren texture and the occurrence of a larger amount of melt in the vicinity of 
opaque minerals and inside primary fractures, as well as because of the deformation microstructures of pyroxenes that occur at the rims of the silica and feldspar-rich melt pockets. The occurrence of pseudotachylite-like veins and schlieren structures indicates that the source area of the meteorite might be the rim area of the crater (Kenkmann et al. 2000). The shock features in Zagami meteorite have been formed prior to the impact that caused its excavation and its launch to the space.

\section{Acknowledgements}

This study was supported by the COST-STSM TD1308-010215-053644-53644 research grant, the Eötvös Scholarship of the Tempus Foundation (MAEÖ_2016-1), and the microprobe analysis was supported by the GINOP 2.3.2-15-2016-00009, while the research aspects related to the impact processes were supported by the GINOP-2.3.2-15-2016-00003 project. The authors are grateful to Zuárd Ditrói Puskás and to an anonymous reviewer for helpful suggestions in the manuscript.

\section{References}

Chen, M., X. Xie, A.E. Goresy 2004: A shock-produced (Mg, Fe) $\mathrm{SiO}_{3}$ glass in the Suizhou meteorite. Meteoritics \& Planetary Science, 39/11, pp. 1797-1808.

Darling, J., C. Storey, C. Hawkesworth 2009: Impact melt sheet zircons and their implications for the Hadean crust. - Geology, 37/10, pp. 927-930.

Dingwell, D.B., S.L. Webb 1989: Structural relaxation in silicate melts and non-Newtonian melt rheology in geologic processes. - Physics and Chemistry of Minerals, 16/5, pp. 508-516.

El Goresy, A., M. Chen, P. Gillet, L. Dubrovinsky 2000: Shock-induced high-pressure phase-transition of labradorite to hollandite "(Na47-Ca51-K2)" in Zagami and the assemblage hollandite "(Na80-Ca12-K8)" + jadeite in L chondrites: Constraints to peak-shock pressures. - Meteoritics and Planetary Science Supplement, 35, p. A51.

Eugster, O., A. Weigel, E. Polnau 1997: Ejection times of Martian meteorites. - Geochimica et Cosmochimica Acta, 61/13, pp. 2749-2757.

Forsythe, L.M., R.L. Nielsen, M.R. Fisk 1994: High-field-strength element partitioning between pyroxene and basaltic to dacitic magmas. - Chemical Geology, 117/1-4, pp. 107-125.

Fricke, A., O. Medenbach, W. Schreyer 1990: Fluid inclusions, planar elements and pseudotachylites in the basement rocks of the Vredefort structure, South Africa. - Tectonophysics, 171/1, pp. 169-183.

Fritz, J., N. Artemieva, A. Greshake 2005: Ejection of Martian meteorites. - Meteoritics \& Planetary Science, 40/9-10, pp. 1393-1411.

Graham, A.L., A.W.R. Bevan, R. Hutchison 1985: Catalogue of Meteorites (4th ed.). - University of Arizona Press, Tucson, $460 \mathrm{p}$.

Hawkesworth, C.J., N.W. Rogers, P.W.C. van Calsteren, M.A. Menzies 1984: Mantle enrichment processes. - Nature, 311, pp. 331-335.

Hicks, L.J., J.C. Bridges, S.J. Gurman 2014: Ferric saponite and serpentine in the nakhlite Martian meteorites. - Geochimica et Cosmochimica Acta, 136, pp. 194-210.

Hopkins, M., T.M. Harrison, C.E. Manning 2008: Low heat flow inferred from $>4$ Gyr zircons suggests Hadean plate boundary interactions. - Nature, 456/7221, pp. 493-496.

Hu, S., Y. Lin, J. Zhang, J. Hao, L. Feng, L. Xu, W. Yang, J. Yang 2014: NanoSIMS analyses of apatite and melt inclusions in the GRV 020090 Martian meteorite: Hydrogen isotope evidence for 
recent past underground hydrothermal activity on Mars. - Geochimica et Cosmochimica Acta, 140, pp. 321-333.

Kayama, M., H. Nishido, T. Sekine, T. Nakazato, A. Gucsik, K. Ninagawa 2012: Shock barometer using cathodoluminescence of alkali feldspar. - Journal of Geophysical Research: Planets, 117/E9, E09004, 13 p.

Kelemen, P.B., S.R. Hart, S. Bernstein 1998: Silica enrichment in the continental upper mantle via melt/rock reaction. - Earth and Planetary Science Letters, 164/1, pp. 387-406.

Kenkmann, T., U. Hornemann, D. Stöffler 2000: Experimental generation of shock-induced pseudotachylytes along lithological interfaces. - Meteoritics and Planetary Science, 35, pp. 1275-1290.

Kong, P., X. Xie 2003: Redistribution of elements in the heavily shocked Yanzhuang chondrite. Meteoritics \& Planetary Science, 38/5, pp. 739-746.

Lafuente, B, R.T. Downs, H. Yang, N. Stone 2015: The power of databases: The RRUFF project. - In: Armbruster, T., R.M. Danisi (Eds): Highlights in mineralogical xrystallography. W. De Gruyter, Berlin, pp. $1-30$.

Langenhorst, F., J.P. Poirier 2000: Anatomy of black veins in Zagami: Clues to the formation of highpressure phases. - Earth and Planetary Science Letters, 184/1, pp. 37-55.

Langenhorst, F., D. Stöffler, D. Klein 1991: Shock metamorphism of the Zagami achondrite. - Lunar and Planetary Science Conference, 22, pp. 779-780.

Madsen, M.B., M. Olsen, J.M. Knudsen, D. Petersen, L. Vistisen 1992: The ferrigmagnetic phase in Nakhla and Zagami - Implications for the Martian fines. - Lunar and Planetary Science Conference, 23, pp. $825-826$.

Malavergne, V., F. Guyot, K. Benzerara, I. Martinez 2001: Description of new shock-induced phases in the Shergotty, Zagami, Nakhla and Chassigny meteorites. - Meteoritics \& Planetary Science, 36/10, pp. 1297-1305.

Marti, K., J.S. Kim, A.N. Thakur, T.J. McCoy, K. Keil 1995: Signatures of the Martian atmosphere in glass of the Zagami meteorite. - Science, 267, pp. 1981-1984.

McCoy, T.J., G.J. Taylor, K. Keil 1992: Zagami: Product of a two-stage magmatic history. - Geochimica et Cosmochimica Acta, 56/9, pp. 3571-3582.

McCubbin, F.M., H. Nekvasil 2008: Maskelynite-hosted apatite in the Chassigny meteorite: Insights into late-stage magmatic volatile evolution in Martian magmas. - American Mineralogist, 93/4, pp. 676-684.

Mikouchi, T., M. Miyamoto, G. McKay 1999: The role of undercooling in producing igneous zoning trends in pyroxenes and maskelynites among basaltic Martian meteorites. - Earth and Planetary Science Letters, 173, pp. 235-256.

Min, K.K., A. Farah 2011: (U-Th)/He Ages from Martian Meteorites Zagami and ALHA77005: Their implications to shock temperatures. - AGU Fall Meeting Abstracts, San Francisco, CA, Abstract ID P11C-1600.

Miura, Y., M. Okamoto, O.G. Iancu 1993: Ejection process of Martian meteorites from shock metamorphism. - Meteoritics, 28, pp. 402-403.

Nemchin, A.A., M. Humayun, M.J. Whitehouse, R.H. Hewins, J.P. Lorand, A. Kennedy, M. Grange, B. Zanda, C. Fieni, D. Deldicque 2014: Record of the ancient Martian hydrosphere and atmosphere preserved in zircon from a Martian meteorite. - Nature Geoscience, 7/9, pp. 638-642.

Nyquist, L.E., D.D. Bogard, C.Y. Shih, A. Greshake, D. Stöffler, O. Eugster 2001: Ages and geologic histories of Martian meteorites. - Space Science Reviews, 96/1-4, pp. 105-164.

Osinski, G.R. 2007: Impact metamorphism of CaCO3-bearing sandstones at the Haughton structure, Canada. - Meteoritics \& Planetary Science, 42/11, pp. 1945-1960.

Reimold, W.U., C. Koeberl, F. Brandstatter, F.J. Kruger, R.A. Armstrong, C. Bootsman 1999: Morokweng impact structure, South Africa: Geologic, petrographic, and isotopic results, and implications for the size of the structure. - Geological Society of America, Special Paper 339, pp. 61-90.

Sharp, T.G., P.S. De Carli 2006: Shock effects in meteorites. - In: Lauretta, D.S., H.Y. McSween (Eds): Meteorites and the Early Solar System II. University of Arizona Press, Tucson, pp. 653-677.

Stöffler, D., K. Keil, E. Scott, E. 1991: Shock metamorphism of ordinary chondrites. - Geochimica et Cosmochimica Acta, 55, pp. 3845-3867. 
Treiman, A.H. 2005: The nakhlite meteorites: Augite-rich igneous rocks from Mars. - Chemie der Erde-Geochemistry, 65/3, pp. 203-270.

Vickery, A.M., H.J. Melosh 1987: The large crater origin of SNC meteorites. - Science, 237/4816, pp. 738-743.

Walton, E.L., C.S. Shaw 2009: Understanding the textures and origin of shock melt pockets in Martian meteorites from petrographic studies, comparisons with terrestrial mantle xenoliths, and experimental studies. - Meteoritics \& Planetary Science, 44/1, pp. 55-76.

Walton, E.L., J.G. Spray 2003: Mineralogy, microtexture, and composition of shock-induced melt pockets in the Los Angeles basaltic shergottite. - Meteoritics \& Planetary Science, 38/12, pp. 1865-1875.

Wark, D.A., J.F. Lovering 1977: Marker events in the early evolution of the solar system-Evidence from rims on $\mathrm{Ca}-\mathrm{Al}$-rich inclusions in carbonaceous chondrites. - Lunar and Planetary Science Conference Proceedings, 8, pp. 95-112.

Warren, P.H. 1994: Lunar and Martian meteorite delivery services. - Icarus, 111, pp. 338-363.

Watson, E.B., D.A. Wark, J.B. Thomas 2006: Crystallization thermometers for zircon and rutile. Contributions to Mineralogy and Petrology, 151/4, pp. 413-433.

Westall, F. 2016: Chapter 6: The Geological Context for the Origin of Life, and Mineral Signatures of Fossil Life. - In: Gargaud, M., B. Barbier, H. Martin, J. Reisse (Eds): Lectures in Astrobiology. Springer Science \& Business Media, Berlin, 1, pp. 195-226.

Wielicki, M.M., T.M. Harrison 2015: Zircon formation in impact melts: Complications for deciphering planetary impact histories. - Geological Society of America, Special Paper 518, pp. 127-134. 